Chemotherapy 1995;41(suppl 1):I-III

\title{
Contents, Vol. 41, Supplement 1,1995
}

Gorbach, S.L. Foreword $\quad 1$

Scarpignato, C; Rampal, P. Preface3

Salminen, S.; Isolauri, E.; Onnela, T. Gut Flora in Normal and Disordered States 5

Thoren, A. Enteric Infections in the Traveler: A Socioeconomic Perspective 16

Castelli, F.; Carosi, G.Epidemiology of Traveler's Diarrhea 20

DuPont, H.L. Pathogenesis of Traveler's Diarrhea 33

Katelaris, P.H.; Farthing, M.J.G. Traveler's Diarrhea: Clinical Presentation and Prognosis 40

Scarpignato, C; Rampal, P. Prevention and Treatment of Traveler's Diarrhea: A Clinical

Pharmacological Approach 48

Author Index Vol. 41, Suppl. 1,1995 82

Subject Index Vol. 41, Suppl. 1,199582

in 